УДК 1:291.1

DOI: 10.18101/1994-0866-2020-1-81-87

\title{
НЕОЯЗЫЧЕСТВО В СОВРЕМЕННОЙ РОССИИ: ИСТОРИКО-ФИЛОСОФСКИЙ АНАЛИЗ
}

\author{
(c) Ахмадулина Светлана Зиннатовна \\ кандидат исторических наук, \\ Бурятский государственный университет имени Доржи Банзарова \\ Россия, 670000, г. Улан-Удэ, ул. Смолина, 24а \\ E-mail: lana_clio@mail.ru

\section{(c) Федоров Михаил Александрович} \\ кандидат филологических наук, \\ Бурятский государственный университет имени Доржи Банзарова \\ Россия, 670000, г. Улан-Удэ, ул. Смолина, 24а \\ E-mail: fma1105@gmail.com
}

Статья посвящена историко-философскому анализу неоязычества в современной России. В работе прослежен путь инкорпорации неоязыческих представлений в изменившихся политических и социокультурных условиях жизни страны в постсоветский период времени. Основой неоязыческого мировоззрения выступают дохристианские языческие верования древних славян, религиозные представления, заимствованные из современного оккультизма и верований других народов. Авторы приходят к выводу о том, что неоязычники утверждают «этническую чистоту», которая предназначена противостоять релятивизирующим и культурно деструктивным влияниям всех подобных зарубежных тенденций. В основе интересов неоязычников, помимо различных праздников, обрядов, лежит интерес к народной магии, который широко распространен даже среди практикующих христиан, и грань между оккультизмом, магией, парапсихологией и религией гораздо более размыта, чем она есть на самом деле во многих западных странах. Эта культурная преемственность является особенностью для России. Неоязычество отвечает на потребности в архаическом мышлении, реконструкции родовых связей, магии, экологии и новой идентичности на фоне глобальных проблем современности и в условиях глобализационных процессов.

Ключевые слова: неоязычество; родноверие; Союз славянских общин славянской родной веры; П. К. Иванов; гуманизм; антигуманизм; субкультура.

\section{Для цитирования}

Ахмадулина C. 3., Федоров M. А. Неоязычество в современной России: историкофилософский анализ // Вестник Бурятского государственного университета. Философия. 2020. Вып. 1. С. 81-87.

Глобальные социокультурные изменения начала XXI в. трансформируют привычные мировоззренческие ориентиры, традиционные системы духовных ценностей, устоявшиеся модели самоидентификации, что приводит к возникновению альтернативных построений социальной, духовно-нравственной жизни. Ярким примером служит возрождение языческого мировоззрения в новой форме. Изучение данного феномена с по- 
зиции философско-антропологического подхода обусловлено дестабилизационным потенциалом, которым обладают подобные религиозные новации. В религиозной сфере дестабилизационный потенциал проявляется в возникновении и широком распространении различных псевдорелигиозных языческих движений и групп, противопоставляющих себя традиционным духовным ценностям; в политической сфере выражается в росте националистических настроений; в области культуры - пропаганде ценностей и норм поведения альтернативных общепринятым, основанным на обращении к истинным историческим корням народа, специфическим формам природного окружения $\quad$ и др.

Современное неоязычество имеет под собой серьезную философскую основу, в частности идеи Фридриха Ницше теоретический антигуманизм: индивидуальноличностное начало в культуре, окончательная смерть человека. При этом сам философ, отрицая христианские ценности, пришел к новому типу гуманизма, который закладывает культуру будущего. Возникновение неоязычества сегодня одно из актуальных направлений современной философии, основанное на крушении идей гуманизма в результате культурно-философской рефлексии над событиями, связанными со Второй мировой войной.

Развитие неязыческого направления в рамках философской науки проходит несколько этапов. Как правило, первый связывают с деятельностью франкфуртской философской школы. Представители школы приходят от антигуманизма к утверждению гуманизма, акцентируя внимание на том, что все проблемы человечества лежат в научнотехнической рациональности, воплощенной в общественной жизни (М. Хоркхаймер, Т. Адорно) [12].

Вторым периодом развития неоязычества в рамках философии является постмодернистский. Это, прежде всего, идеи Ж. Лиотара [7], который считал, что для современной культуры характерно «языческое» переосмысление ценностей в пространстве культурно-игровой деятельности индивида.

В 1970-1980-е гг. в странах Запада и США возникает новая правая философия, представители которой призывали к радикальному уничтожению существовавшего типа рациональности и гуманизма в культуре Европы, ставшему основной причиной ее духовного кризиса.

В последние десятилетия неоязыческая философия связывается с именем французского философа, основателя и теоретика движения «Новые правые» Алена Де Бенуа и его сторонников (Ж. Дюмезиля, Ж. Бержье, Л. Повеля, П. Шоню и др.) [4; 5; 6; 13]. В одной из своих работ А. Бенуа доказывает, что «язычество - это не только далекое прошлое человечества, но и, в новой форме, наше неотвратимое будущее, лишенное иудео-христианского мусора» [4]. По мнению представителей современной неоязыческой философии, феномен неоязычества порожден современными проблемами человечества, основаны на социокультурных мифах древности, транслирующимися в современной западной культуре. Следовательно, неоязычество будет существовать до тех пор, пока будут сохраняться факторы, способствующие его сохранению.

Обратимся к историческим особенностям возникновения и развития неоязыческих представлений в России. В изменившихся политических и социокультурных условиях в современной России, наряду с возрождением традиционных религиозных ценностей, сохранением атеистических взглядов среди определенной части населения, в страну проникают различные новые религиозные движения, проводниками которых становятся 
западные и восточные миссионеры. Массовая религиозная конверсия россиян сопровождалась реконструкцией архаических форм верований в новой форме. В современной конфессионально ориентированной и светской литературе этот феномен чаще всего употребляют как «неоязычество».

Анализируя механизм возникновения неоязыческих культов, В. В. Напольских одной из основных черт неоязычества называет противопоставления «высокой» религии, где развитый культ ориентирован на элиту, определяемую в социально-культурном или интеллектуальном аспектах, религиозным воззрениям «простого народа», инаковость которых актуализируется через интерпретацию содержания «высокой» религии либо через ее упрощение, либо через отрицание [10, с. 139]. Считаем, что данный принцип является универсальным, поскольку нетрадиционные религиозные движения (НРД) возникают в контексте существующих религиозных систем и, следовательно, их содержание не может не коррелировать с уже знакомыми символами и практиками.

В случае неоязычества существование данной бинарной оппозиции обусловлено тем, что в российском культурном пространстве языческие традиции не представлены в системном виде, а существуют в виде отрывков знаний и отдельных обрядов, носящих прагматически-утилитарный характер (заговоров, суеверий). Это обусловливает необходимость воссоздания системы верований фактически заново, в результате чего наблюдается отсутствие единой организационной структуры и зачастую разобщенность взглядов и представлений адептов. В случае НРД противопоставленность высокой религии играет роль не только самоидентификации, но и «автоконструирования», где семантика нового учения создается за счет «высокой» религии, выступающей невольным донором.

С точки зрения генезиса НРД как культурного феномена подобное донорство неизбежно. Э. С. Маркарян указывает на то, что в основе генезиса культурных феноменов находится диалектика традиции и инновации, где новое не только уравновешивается, но и легитимизируется знакомым и усвоенным содержанием [8, с. 154].

В философском дискурсе неоязычество коррелируется с концептуальными построениями, исходящими из идеи органицизма как установки на утверждение онтологической укорененности сущего и его изначально биоморфного характера. Современная философская рефлексия все чаще обнаруживает постоянно нарастающие неоязыческие мотивы и явное смещение акцентов в трактовке рациональности. Среди наиболее репрезентативных и показательных в этом отношении можно назвать концептуальные проекты «рекультивации архаики» и «новой метафизики». Так, в «новой метафизике», заявляемой в качестве гуманитарной парадигмы философствования XXI в., неоязычество определяется как общая траектория эволюции философского дискурса последних двух столетий, направленная от онтологии к гносеологии и далее через аксиологию и культурологию к персонологии. Иными словами, «неоязычески размерная» философия современности претендует на интимизированное, личностно ориентированное и персоналистически окрашенное понимание бытия и взаимоотношений человека с ним [9].

Наиболее распространенным в России является так называемое родноверие, основой которого выступают дохристианские языческие верования древних славян, а также религиозные представления, заимствованные из современного оккультизма и верований других народов. Сложность в изучении родноверия заключается в отсутствии единой организационной структуры, зачастую разобщенности взглядов и представлений адептов. 
В современной России существует запрет на деятельность некоторых неоязыческих групп, многие из которых были признаны экстремистскими в связи с радикальностью их взглядов. Неоязычество - это чаще всего субкультурное явление религиозного и/или общественно-политического характера, практически не поддающееся контролю и изучению со стороны как органов государственной власти, так и общественности, ученых, прежде всего из-за своей разнородности.

К родноверческим группам в России относится Союз славянских общин славянской родной веры (далее - Союз), базирующийся в Калуге. Самый большой культ - это культ великого бога Рода. К меньшим божествам относятся Перун и Даждьбог. Российские центры родноверов расположены также в Долгопрудном, Пскове и других городах. В Москве есть несколько языческих храмов.

Основная деятельность Союза, которая началась в 1997 г., заключается в изучении, следовании и развитии исконных религиозно-нравственных, культурных традиций славянского этноса. Основным направлением деятельности выступает просвещение, возрождение и развитие ремесленного производства, промыслов и др. Образовательный процесс осуществляется посредством создания сообществ в социальных проектах в сети Интернет. Существует свой собственный опыт издательской деятельности. Первое российское печатное издание Союза представлено журналом «Родноверие». Всего с 2009 по 2019 г. было опубликовано 14 выпусков журнала. С 2008 г. действует образовательный проект «Училище Родной Веры Славян», который представляет собой обучающие курсы о славянском язычестве, обрядах, общине, этнографии, фольклоре, древних святилищах и имеет свою базу для практических занятий.

Спортивно-патриотическое, трудовое воспитание детей и молодежи представлено славянскими праздниками, народными игрищами, экологическими и этнотуристическими слетами. Начиная с 2011 г. действует культурно-этнографический, экологический комплекс «Красотынка». Создаются славянские творческие коллективы, фольклорные группы, поддержкой пользуются мастера традиционных видов единоборств, развиваются народные ремесла, промыслы, проводятся этнографические экспедиции и др.

Посттеософские и космоэкологические движения, включая Живую этику и Агнийогу, движения Николая и Елены Рерих (рерихианство), а также ариософские и ведические движения, периодически пропагандировавшие теорию о том, что славяне в основном - это потомки доисторических ариев. Интерес к языческой тематике связан со стремлением к «вечной философии» и развитию национально ориентированной «языческой политической культуры».

В современной России неоязычество также ассоциируют с движением последователей Порфирия Корниевича Иванова, основателя системы естественного здоровья и философии. Несколько тысяч членов церкви в России следуют заветам Иванова, которые включают еженедельное голодание, купание в холодной «чистой» воде и строгие правила руководство речью и поведением. Возникшее в первой половине $\mathrm{XX}$ в. это движение не теряет своей актуальности сегодня. С одной стороны, Порфирий Иванов претендует на мессианскую роль после особого «просветления», «вселения Духа Святого», с другой - отрицает бессмертность человеческой души, загробного мира, наличие ада и рая. В основе его учения лежит отрицание Иисуса Христа, земная человеческая жизнь, одухотворение сил природы и стремление занять место Христа-Спасителя «животворящим Порфирием Корнеевичем Ивановым» [11]. 
Причина привлекательности многих неоязыческих культов лежит в обещании полного исцеления от всех болезней. К примеру, в казахском движении Эллэ Аят для этого необходимо прикладывать журнал «Звезда Селенной» к больному месту (даже при наличие онкологических заболеваний), смотреть на солнце в определенные часы дня, пить эткен чай и участвовать в аятах; у ивановцев для достижения цели используется механизм закаливания, основанный на обливании холодной водой и принятии воздушных ванн, с призывами и обращениями к учителю о даровании энергии, голодании и в целом аскетичного образа жизни [1, с. 189-194].

Известный исследователь культа П. Иванова религиовед Е. Г. Балагушкин считает, что система, предложенная Ивановым в его кодексе «Детка», воспринимается некоторыми последователями как способ избавления человека от неблагоприятных воздействий условий урбанизированного, индустриального общества. Для других это ностальгия, связанная с утратой близкой к природе сельской здоровой жизни, и стремление найти средства природного оздоровления в условиях достаточно слабой физкультурноспортивной работы и низкого медицинского обслуживания населения. Нравственные наставления П. К. Иванова, основанные на доброжелательном отношении между людьми, вызывает симпатию у тех, кто испытывает стресс от «обезличенных и разобщенных отношений в современном "машинизированном" обществе» [3, с. 59-115].

На другом конце спектра связанных с язычеством альтернативных религий находятся сатанистские группы, которые, как известно, возникли в различных регионах страны, в том числе и в Республике Бурятия. На сегодняшний день численность последователей церкви Сатаны в Бурятии составляет примерно 30-40 чел. Несмотря на то, что сатанизм рассматривается как антихристианское движение, которое лишь незначительно (если вообще) связано с дохристианскими традициями, его часто причисляют к неоязычеству. Языческие, оккультистские, сатанистские, ультранационалистические и расистские темы «белой силы» в различных сочетаниях и политические перегибы - все можно найти циркулирующими на полях хеви-метал и готик-рок субкультуры.

Как было уже отмечено, наряду с сохранением устойчивых позиций традиционных конфессий возникают новые религиозные движения и культы, возрождаются древние языческие представления в форме неоязычества. В региональном аспекте этот процесс имеет свои особенности, т. к. Байкал сегодня — центр притяжения для различных религиозных новаций, в том числе и неоязыческих. В силу многоконфессиональности республики, формирования бытовой религиозной практики, группа родноверов, деятельность которых сосредоточена в Улан-Удэ с 2013 г., пытается противопоставить себя местным религиозным верованиям. Так, за г. Улан-Удэ в районе Верхняя Березовка на одном из протекающих лесных ручьев расположено деревянное изображение солнца (было разрушено. - С. 3.), рядом надпись «монетки не бросать - это русский Бог». Главой общины «Родовичи» является Велемир Москвитин, его супруга Светозара имеет свою собственную мастерскую «Жар-птица», где изготавливают обереги, рушники, очелья, народную стилизованную одежду [2, с. 66-67].

Различного рода тренинги, интерактивные практики, медитации, расстановки ежегодно проводятся на берегу Байкала. Наличие необходимых условий - вода, солнечная энергия. Например, одна из таких групп - «Сила Рода» - летом 2013 г. провела байкальские психологические тренинги на курорте Горячинск. Основная тематика встреч была связана с обретением Силы Рода и сохранением этой связи, построением родового 
дерева с соблюдением системных законов, работой с родовыми сценариями, использованием ресурсов рода, исцеления и разрушения родовых проклятий. Сложность изучения подобных групп связана с трудностими идентификации и причисления к определенной религиозной группе.

В Бурятии также действует группа последователей П. К. Иванова в г. Улан-Удэ, о численности и составе информации практически нет. Рериховское движение было представлено в Улан-Удэ рериховским обществом, встречи проводила ассоциация «Мир через культуру» в Национальной библиотеке. В г. Северобайкальске действовал молодежный центр «Урусвати - Утренняя звезда», члены рериховского движения должны были построить «Город Солнца» как паломнический центр для всех мировых религий на выделенном администрацией города земельном участке.

По данным на 2016 г. в Улан-Удэ появилась сатанистская секта под названием «Суккуба» - так называемые люциферианцы. Изначально суккуб - средневековый демон, олицетворяющий разврат и похоть. В секту входило около $30-40$ человек, свою деятельность они проводили в центре города в одном из неприметных офисов, также была создана закрытая группа в соцсети «ВКонтакте». О дальнейшей деятельности данной организации ничего неизвестно. В том же году в районе Верхняя Березовка были найдены следы сатанистов, а именно: посаженные на кол тушки животных, территория была обозначена ритуальными камнями, повсюду были разбросаны потухшие факелы. Многие считают, что это проделки людей, но большинство настаивает на деятельности сатанистов, правда это или нет, мы, к сожалению, сказать не можем

В заключение отметим, что неоязычники утверждают «этническую чистоту», которая, по их мнению, должна противостоять релятивизирующим и культурно деструктивным влияниям всех подобных зарубежных тенденций. В основе интересов неоязычников, помимо различных праздников, обрядов, лежит интерес к народной магии, который широко распространен даже среди практикующих христиан, и грань между оккультизмом, магией, парапсихологией и религией гораздо более размыта, чем во многих западных странах. Эта культурная преемственность является особенностью для России. Неоязычество отвечает на потребности в архаическом мышлении, реконструкции родовых связей, магии, экологии и новой идентичности на фоне глобальных проблем современности и в условиях глобализационных процессов.

\section{Литература}

1. Ахмадулина С. 3. Правовое регулирование нетрадиционных религий в России. УланУдэ, 2019. $280 \mathrm{c}$.

2. Ахмадулина С. 3. Новые религиозные объединения // Религиозные организации Республики Бурятия: словарь-справочник / С. В. Васильева [и др.]. Улан-Удэ, 2011. 238 с.

3. Балагушкин Е. Г. Нетрадиционные религии в современной России: морфологический анализ. М., 1999. Ч. 1.244 с.

4. Бенуа А. Как можно быть язычником. М.: Русская правда, 2004. 240 с.

5. Бержье Ж., Повель Л. Утро магов / сокр. пер. с фр. Е. Патуева-Иванова. М.: Миф, $1991.79 \mathrm{c}$

6. Дюмезиль Ж. Верховные боги индоевропейцев. М.: Наука, 1986. 234 с.

7. Лиотар Ж.-Ф. Состояние постмодерна. М.: Институт экспериментальной социологии. СПб.: Алетейя, 1998. 160 с

8. Маркарян Э. С. Теория культуры и современная наука. М., 1983. 279 с. 
9. Михеева И. Б. Неоязычество как религиозно-культурный феномен современности: проблема дефиниции [Электронный ресурс] // Ценности и смыслы. 2010. № 1. С. 81-90. URL: http://masters.donntu.org/2015/fknt/ovsianikova/library/article6.htm (дата обращения: 20.01.2020).

10. Напольских В. В. Заметки на полях. Неоязычество на просторах Евразии // Вестник Евразии. 2002. № 1. С. 138-146.

11. Современные секты в России // Вестник Всецерковного Православного Молодежного движения / под. ред. С. Е. Прокофьева. Спец. вып. 1995. 80 с.

12. Хоркхаймер М., Адорно Т. В. Культурная индустрия: просвещение как способ обмана масс / пер. Т. Зборовской. М.: Ад Маргинем Пресс, 2016. 103 с.

13. Шоню П. Во что я верую / пер. с фр. и примеч. Г. И. Семенова. М.: Русский путь, 1996. $286 \mathrm{c}$.

\title{
NEOPAGANISM IN MODERN RUSSIA: \\ A HISTORICAL AND PHILOSOPHICAL ANALYSIS
}

\author{
Svetlana Z. Akhmadulina \\ Cand. Sci. (History), \\ Dorzhi Banzarov Buryat State University \\ 24a Smolina St., Ulan-Ude 670000, Russia \\ E-mail: lana_clio@mail.ru
}

Mikhail A. Fyodorov

Cand. Sci. (Phil.),

Dorzhi Banzarov Buryat State University

24a Smolina St., Ulan-Ude 670000, Russia

Email: fma1105@gmail.com

The article presents a historical and philosophical analysis of neopaganism in modern Russia. We have traced the incorporation of neopagan ideas in the changed political and sociocultural environment of post-Soviet Russia. The foundation of the neopagan worldview is the preChristian pagan beliefs of the ancient Slavs, based on the preserved historical data, their own religious ideas borrowed from modern occultism and the beliefs of other peoples. We have concluded that neopagans claim "ethnic purity", which is meant to withstand the relativistic and culturally destructive influences of similar foreign trends. The interests of neopagans in addition to various feast days and ceremonies involve folk magic, which is widespread even among practicing Christians; and a borderland between occultism, magic, parapsychology and religion is much more blurred than it actually is in many Western countries. This cultural continuity is Russia's unique feature. Neopaganism responds to the needs for archaic thinking, reconstruction of patrimonial ties, magic, ecology and new identity against the background of present global problems and globalization processes.

Keywords: neopaganism; the Union of Slavic Communities of the Slavic Native Belief; P. K. Ivanov; humanism; anti-humanism; subculture. 